VADYM KOROBKA,

Mariupol State University (Mariupol, Ukraine)

e-mail:v.korobka@mdu.in.ua, ORCID 0000-0002-2030-498X

YULIIA KOROBKA,

Mariupol State University (Mariupol, Ukraine)

e-mail: j.korobka@mdu.in.ua, ORCID 0000-0003-4518-4264

\title{
ADMINISTRATIVE SUPERVISION OVER THE ACTIVITIES OF THE CITY SELF-GOVERNMENTS OF THE EKATERINOSLAV PROVINCE (1870 - 1913) (part 2) ${ }^{1}$
}

The article reveals the importance of administrative supervision over city self-governments in the Ekaterinoslav Province (1870-1913). Their social orientation has been established. Expenses provided a priority increase in expenditures on schooling and medicine, veterinary and sanitary units. State control institutions generally did not interfere with the budget policy of municipal self-government institutions and its humanitarian component, although misunderstandings sometimes arose.

It has been revealed that the implementation of state control over public administrations in the Ekaterinoslav Province often faced the aspirations of self-government bodies in secondary issues of municipal organization which were incom-patible with the law in the opinion of its hosts. Disputes arose mostly on the basis of different understandings of the rules of sale and purchase of goods, measures to regulate traffic on city streets etc.

It has been confirmed that in exercising their powers in the field of control over the compliance with the law by city self-governments, state institutions of the provincial level sometimes showed inappropriate competence in the field of interpretation of imperial legislation, which resulted in erroneous decisions. Certain decisions of public administrations of cities also sometimes violated imperial law and were subject to unconditional termination or revocation.

It has been proved that the public administrations of the Province widely used the legally regulated opportunity to defend their decisions in the Senate. The specific Senate cases started in connection with the supervision over the legality of decisions of city self-governments and the provincial presence for the zemstvo and city affairs give the impression that they were considered on the basis of a qualified verification of compliance with imperial law.

It has been established the administrative control was implemented slowly, and formulations of thoughts on appealing the decisions of the Provincial Presence were deprived of speed and efficiency. The provincial zemstvo sinned against evading operative decisions. At the same time, there was a dishonest delay in the circulation of documents in all parts of public administration and local self-government.

Key words: Ekaterinoslav Province; city public administration; self-government; Ekaterinoslav provincial presence for the zemstvo and city affairs; Senate; City Duma; city budget.

\section{Introduction}

The relevance of the problem. One of the most important aspects of state supervision was the income of the revenue of city estimates and expenditures - the material basis for public administration to address issues of local importance. Tsarism created a legal basis for the implementation of careful control over the accumulation and expenditure of financial resources needed to fulfil the commitments of city self-governance, as well as other areas of municipal government.
From the journalism of the imperial era to the historical literature of our time, there are reflections on the governor's arbitrariness and obstruction of the Heads of provinces in the implementation of the principles and competencies of self-government in the cities. Given the above, clarifying the historical importance of state control over public administration of cities seems to be an essential element in the study of the role of local self-government in Ukraine as an important area of urban history.

\footnotetext{
${ }^{1}$ The first part of the article is published in the journal "SKHID". Volume 2 (1) March-April 2021 on pages 5-11.
} 
The purpose of the article is to reveal the importance of administrative supervision over the city selfgovernments in the Ekaterinoslav Province (1870-1913).

\section{Research methodology}

The main principles of the research methodology are described in the first part of the article. In addition, quantitative methods were used to analyze the population growth of cities, revenues and expenditures of urban settlements of Ekaterinoslav Province. The calculation of growth rates of city revenues and expenditures is based on the applied statistical data of historical sources updated by us.

\section{Results of research and discussion}

Supervision over budget policy by the state administration as a complex area of self-government practice affected the Novomoskovsk public administration as well. In particular, in 1895, in the cost estimate of Novomoskovsk for 1896, 5000 rubles were allocated for the construction of the bell tower. The Head of the province had doubts about the ability of Novomoskovsk municipalities to ensure compliance with the planned budget expenditures and the calculated plan of revenues to the city budget. On March 11, 1897, the Provincial Presence excluded allocations for the construction of the bell tower from the budget without considering the explanation of the City Duma about the possibility of eliminating the danger of lack of fund.

The Senate, for its part, considering the complaint of the Novomoskovsk Mayor in this regard, explained that the City Duma did not act beyond its powers when it included costs necessary for the construction of the bell tower in the budget and indicated the source of its coverage (arrears of previous years). Strengthening the argument in favor of the Novomoskovsk City Duma, the Senate noted that under art. 4 of the City Regulations, city public administrations were responsible for taking care of Orthodox churches and maintaining them in good condition. After all, the complaint of the Novomoskovsk Mayor was satisfied: due to the identified shortcomings, the decision of the Presence was revoked and at the same time it was entrusted with reconsidering the case (Kantorovich, 1903: 758).

Expenditure on police maintenance was very burdensome for city budgets. Institutions of self-governance tried to limit at least the increase in spending on city law enforcement officers, which often led to serious disagreements with the imperial administration. For example, the Novomoskovsk city self-government had a dispute with the Minister of the Interior over the police personnel in the city. On April 10, 1904, the Novomoskovsk City Duma passed a resolution to petition the Minister of the Interior to reduce the number of police personnel from 31 to 26 on the following grounds. According to the information of the Statistical Committee of the Ministry of Internal Affairs, according to the census of January 28, 1897, there were 12,862 inhabitants in the city of Novomoskovsk. Referring to the legislation that established the rules for calculating the number of city residents relative to the population, the Novomoskovsk City Public Administration insisted that the number of lower-ranking police officers in the city should be 26 (Mantsevich, 1911: 193).

When considering the petition, the Minister of the Interior had contradictory information about the number of residents of Novomoskovsk. On the one hand, he had the rate according to the 1897 census, on the other, there was information received from the Novomoskovsk district ispravnik, as well as from the Review of the Ekaterinoslav Province in 1903. The last two were twice the first (Mantsevich, 1911: 193).

Due to a large discrepancy in the population, by the order of March 31, 1905, the Minister informed the governor that this was an obstacle to granting the request of the Novomoskovsk City Duma. The Minister added that based on information only from the 1897 census, due to natural population growth, which was almost $2 \%$ per year, in Novomoskovsk, the number of urban residents increased by 1,800 people in seven years. In this case, the staff of the Novomoskovsk police team could be reduced only by one policeman. It is unlikely, the Minister reasoned, that the City Duma would decide to insist on this, because the city's expenditure on police maintenance would be reduced by a very small amount (Mantsevich, 1911: 194).

The ministerial order did not stop the Novomoskovsk municipalities. The Mayor appealed against the Minister's order to the Senate. The Senate decree overturned the Interior Minister's order due to a lack of accurate population statistics. At the same time, the Senate found it necessary to mention the need to collect accurate statistics on the population, even to expect a new census (Mantsevich, 1911: 195). Thus, the issue of downsizing of the police personnel remained on the agenda.

The search for sources of income to the city treasuries led the self-government of cities to a clash with stateowned enterprises. The search for sources of income to the city treasury determined the approval of the decision of the Luhansk City Duma of June 2, 1901 to impose an assessment fee in favor of the city buildings of the Luhansk ammunition factory with machines and other factory equipment placed there in 1902 . In this case, the procedure for appealing this decision was initiated by a complaint to the Senate by the Head of the factory, Colonel Somov. The Head of the enterprise explained his disagreement with the decision of the City Duma by the fact that from the day of its foundation the factory had still produced rifle cartridges exclusively for the needs of the army and did not fulfill any private orders and therefore could not be recognized as profitable property. Based on the fact that the company's activities were limited to the manufacturing of a products for public use, the Senate recognized the decision of the Luhansk city public administration to involve the ammunition factory in the payment of the assessment fee baseless (Mantsevich, 1911: 237-238).

By an order of April 25, 1903, the Senate rejected the complaint of Ilarion Maiboroda, the counselor-at-law of the Railways Department, against the resolution of the Luhansk City Duma concerning the imposition of an assessment fee on the residential buildings of the Ekaterinoslav Railway to the city income. This decision was made on the basis of paragraph 8 and note 1 to art. 128 of the City Regulations of 1892 , which clearly stated that such objects of state property were subject to municipal taxation on general grounds (Mantsevich, 1911: 258-260).

A similar case was resolved outside the Senate and with the opposite result. It began with the disagreement (in the form of an order) of the Minister of Railways with the fact that his department had to pay an assessment fee from the buildings of the state Ekaterinoslav Railway, 
occupied by the apartments of its employees, to the income of Ekaterinoslav from 1906. The exact date of the dispute is not known, but according to indirect information, the decision of the City Duma to impose a city tax on railway property could take place in 1905 . By the way, the documents do not record the actions of the Provincial Presence to revoke it. The draft decision on the complaint of the Ekaterinoslav Mayor prepared by the First Department of the Senate did not satisfy the Minister, so the case was postponed to the First General Meeting of the Senate. At this stage of the consideration of the case, on October 20, 1906, various opinions of senators were heard and no decision was made due to the lack of a legally established majority of votes (2/3).

As a result, according to the law, on May 28, 1907, the case was transferred to the State Council, which adopted the relevant provision, highly approved on June 7,1909 . This decision left without effect the complaint of the Ekaterinoslav Mayor and, in fact, overturned the decision of the Ekaterinoslav City Duma on the payment to the city income of an assessment fee from the buildings of the Ministry of Railways occupied by the apartments of railway employees (Mantsevich, 1911: 249-253). The reasoning of the State Council was not subject to verification by the Senate (Blinov, Gagen, Gogel, 1911: 178). Thus, the central body of state administration, which provided transport in the empire, supplementing the dispute with the city self-government of Ekaterinoslav by "heavy artillery" in the form of direct participation of the Minister the Chief of Staff, pushed the necessary decision, which in many respects contradicted current law.
The study of various cases, related to the suspension or cancellation of decisions of city public administrations on filling the income section of city budgets, or receipt of funds for various types of commerce, which was taxed in favor of the city, provides an opportunity to recreate a vivid picture of the difficulties of self-government in the Ekaterinoslav Province. At the same time, it seems that control agencies or other state bodies sometimes abused their right sanctioned by imperial municipal law. Their decisions allegedly hindered the work of city selfgovernment institutions in creating the financial basis of their powers and hindered the implementation of important plans. In the historical literature there are arguments about the constant violation of legislation by governors in the activities of city authorities, which are not confirmed by specific studies (Shandra, 2012: 530).

One way or another, we will try to understand this issue, based on statistical data, which, however, could not be identified by their completeness, accuracy and comprehensiveness, however, reflect certain important properties of development. Firstly, it should be taken into account that all budgetary measures of dumas and councils, as well as administrative supervision over them, took place against the background of a number of important social transformations, such as industrial revolution, migration, including unrestrained flow of people from villages and cities of Russian provinces (Reient, 1993: 13), and urbanization. The Table 1 shows a significant increase in the urban population of the provincial and county centers of the Ekaterinoslav Province from the early 1870s to the First World War.

Table 1. - Population growth of the provincial and county centers of the Ekaterinoslav Province during 1871-1913

\begin{tabular}{|c|c|c|c|}
\hline \multirow{2}{*}{ City } & \multicolumn{2}{|c|}{ Population } & \multirow{2}{*}{$\begin{array}{l}\text { Growth } \\
\text { (times) }\end{array}$} \\
\hline & 1871 & 1913 & \\
\hline Ekaterinoslav & 24267 & 218578 & 9,0 \\
\hline Bakhmut & 17999 & 28256 & 1,6 \\
\hline Verkhnodniprovsk & 4127 & 12640 & 3,1 \\
\hline Luhansk & $15543^{3}$ & 68558 & 4,4 \\
\hline Mariupol & 9037 & 57747 & 6,4 \\
\hline Novomoskovsk & 10515 & 28690 & 2,7 \\
\hline Oleksandrivsk & 5334 & 57609 & 10,8 \\
\hline Pavlograd & 11391 & 30725 & 2,7 \\
\hline
\end{tabular}

In particular, in comparison with the figure of 1871, the population of Oleksandrivsk, Ekaterinoslav, Mariupol, Luhansk (for 1887), Verkhnodniprovsk, Novomoskovsk, Pavlograd and Bakhmut increased by 11, 9, 6, 4, 3, 3, 3 and 2 times (indicators are rounded).

Secondly, population growth was one of the important factors in the growth of urban revenues. As can be seen from the Table 2, during 1872-1913, Ekaterinoslav, Luhansk (for 1884), Oleksandrivsk, Bakhmut, Verkhnodniprovsk, Novomoskovsk, Pavlograd, Mariupol increased the income sections of the city estimates in the appropriate order by $52,30,20,14,14,13,10$ and 8 times.

Table 2 shows that the increase in income led to an increase in expenses in the budgets of the provincial and county cities of Ekaterinoslav Province in 1913 compared with $1872 *$ In particular, Ekaterinoslav, Luhansk (in 1884), Oleksandrivsk, Verkhnodniprovsk, Pavlograd, Bakhmut and Mariupol increased their expenses by $51,32,21,13$, 12,10 and 9 times respectively.

Thirdly, population growth gave rise to complex local imperatives, requiring attention to the health, housing, education, and welfare (Brower, 1990: 125) of residents united by permanent residence within the city. In general, administrative supervision did not prevent the provincial and county cities of the Ekaterinoslav Province from using, as far as possible, the sources legally guaranteed by them to increase revenues and items of expenditure useful to urban communities in general. Among other things, as evidenced by the Table 3 , the expenses of city funds for education increased significantly.

\footnotetext{
- Pamyatnaya knizhka Yekaterinoslavskoy gubernii na 1875 god, 1875: 20; Vsya Yekaterinoslavskaya guberniya na 1913 god (1913): 24-26, 28-31, 33, 35.

Statements for 1887 (Obzor Yekaterinoslavskoy gubernii za 1887 god, 1888: 26).

* A peculiar exception among the county centers of the province mentioned in Part I of our article was Slovianoserbsk, which
} 
Table 2. - Budget income and expenses of county cities of Ekaterinoslav Province in 1872 and 1913

\begin{tabular}{|c|c|c|c|c|c|c|}
\hline \multirow[b]{2}{*}{ City } & \multicolumn{3}{|c|}{ Income $^{4}$} & \multicolumn{3}{|c|}{ Expenses $^{5}$} \\
\hline & year & rubles & $\begin{array}{l}\text { growth } \\
\text { (times) }\end{array}$ & year & rubles & $\begin{array}{l}\text { growth } \\
\text { (times) }\end{array}$ \\
\hline \multirow{2}{*}{ Ekaterinoslav } & 1872 & 48943 & \multirow{2}{*}{51,5} & 1872 & 48992 & \multirow{2}{*}{51,0} \\
\hline & 1913 & 2520914 & & 1913 & 2500248 & \\
\hline \multirow{2}{*}{ Bakhmut } & 1872 & 17721 & \multirow{2}{*}{13,9} & 1872 & 21924 & \multirow{2}{*}{11,5} \\
\hline & 1913 & 245628 & & 1913 & 252894 & \\
\hline \multirow{2}{*}{ Verkhnodniprovsk } & 1872 & 6682 & \multirow{2}{*}{13,6} & 1872 & 7217 & \multirow{2}{*}{12,5} \\
\hline & 1913 & 90612 & & 1913 & 90545 & \\
\hline \multirow{2}{*}{ Luhansk } & 1884 & 8273 & \multirow{2}{*}{29,5} & 1884 & 7678 & \multirow{2}{*}{31,8} \\
\hline & 1913 & 244222 & & 1913 & 244222 & \\
\hline \multirow{2}{*}{ Mariupol } & 1872 & 59068 & \multirow{2}{*}{8,7} & 1872 & 56740 & \multirow{2}{*}{9,1} \\
\hline & 1913 & 514704 & & 1913 & 513514 & \\
\hline \multirow{2}{*}{ Novomoskovsk } & 1872 & 13264 & \multirow{2}{*}{12,9} & 1872 & 17064 & \multirow{2}{*}{10,0} \\
\hline & 1913 & 171510 & & 1913 & 170825 & \\
\hline \multirow{2}{*}{ Oleksandrivsk } & 1873 & 20347 & \multirow{2}{*}{20,0} & 1873 & 19028 & \multirow{2}{*}{21,4} \\
\hline & 1913 & 406836 & & 1913 & 406836 & \\
\hline \multirow{2}{*}{ Pavlograd } & 1872 & 19104 & \multirow{2}{*}{10,3} & 1872 & 20448 & \multirow{2}{*}{12,3} \\
\hline & 1913 & 196443 & & 1914 & 251830 & \\
\hline
\end{tabular}

Table 3. - The growth of expenses of the city treasuries for education, medicine, veterinary medicine and sanitation during 1874-1914 ${ }^{6}$

\begin{tabular}{|c|c|c|c|c|c|c|}
\hline \multirow{4}{*}{ City } & \multicolumn{6}{|c|}{ Expenses of the city treasuries for: } \\
\hline & \multicolumn{3}{|c|}{ education } & \multicolumn{3}{|c|}{$\begin{array}{c}\text { medicine, veterinary medicine } \\
\text { and sanitation }\end{array}$} \\
\hline & 1874 & 1914 & growth & 1874 & 1914 & growth \\
\hline & \multicolumn{2}{|c|}{ rubles } & times & \multicolumn{2}{|c|}{ rubles } & times \\
\hline Ekaterinoslav & 1932 & 330119 & 170,9 & 770 & 333937 & 433,7 \\
\hline Bakhmut & $259^{\prime}$ & 46932 & 181,2 & 1879 & 9695 & 5,2 \\
\hline Verkhnodniprovsk & 859 & 7505 & 8,7 & 465 & 4790 & 10,3 \\
\hline Luhansk & $861^{8}$ & 68230 & 79,2 & $678^{9}$ & 6511 & 9,6 \\
\hline Mariupol & 3500 & 98327 & 28,1 & 89 & 126673 & 1423,3 \\
\hline Novomoskovsk & 620 & $71894^{10}$ & 116,0 & 282 & $7094^{11}$ & 25,2 \\
\hline Oleksandrivsk & 1237 & 97700 & 79,0 & 1911 & 15445 & 8,1 \\
\hline Pavlograd & 440 & 32676 & 74,3 & 481 & 14343 & 29,8 \\
\hline
\end{tabular}

In particular, according to the corresponding order, expenses of city budgets on educational branch increased in 171, 182, 79, 28, 116, 79 and 74 times in 1914 in comparison with 1874 in Ekaterinoslav, Bakhmut (for 1876), Verkhnodniprovsk, Luhansk (for 1886), Mariupol, Novomoskovsk, Oleksandrivsk, Pavlograd respectively. However, the final times of growth were formed through calculations involving negligible initial values, from which the financing of schooling with the implementation of the municipal reform of 1870 began. In the 1900s, financial support of schooling became one of the main items of budget expenditures.
There were positive changes in the health sector and the veterinary part of the city economy compared to the pre-reform period. The expenditures in the field of health care of Ekaterinoslav and Mariupol, which increased from 1874 to 1914 by 434 and 1423 times respectively, are particularly impressive. Here, the city self-governments managed to arrange their own hospitals. And in other cities, public administrations found opportunities only for the establishment of reception wards and financial support of zemstvo hospitals (Korobka, 2010: 12, 13).

In general, city funds were insignificant. This made it difficult to solve many problems. To be fair, it should be

was marked by a slight degree of development of trade and industry that led to the loss of its status as a county center in 1882 . The symbolic increase in the revenues of the city budget in Slovianoserbsk in the county and non-county status, taking into account the increase in prices, meant their actual decrease (Korobka, 2010: 13).

${ }^{4}$ Otchet o denezhnykh oborotakh gorodskikh kass za 1872 god, 1885: 12-15; Otchet ... za 1873 god, 1889: 12-15; Otchet ... za 1884 god, 1885: 12-15; Kratkiy obzor deyatelnosti Yekaterinoslavskoy gorodskoy upravy za 1913 god, 1914: 8-9; Vsya Yekaterinoslavskaya guberniya na 1913 god, 1913: 27, 29-31, 33; Otchet Bakhmutskoy gorodskoy upravy za 1913 god, 1914: 23.

${ }^{5}$ Otchet ... za 1872 god, 1885: 72-75; Otchet ... za 1873 god, 1889: 72-75; Otchet ... za 1884 god, 1885: 74-77; Kratkiy obzor deyatelnosti Yekaterinoslavskoy gorodskoy upravy za 1913 god, 1914: 10-11; Vsya Yekaterinoslavskaya guberniya na 1913 god, 1913: 27, 29-31, 33; Otchet Bakhmutskoy gorodskoy upravy za 1913 god, 1914: 61; Obzor Yekaterinoslavskoy gubernii za 1914 god, $1915: 26-27$.

${ }_{7}^{6}$ Otchet ... za 1874 god, 1889: 72-75; Obzor Yekaterinoslavskoy gubernii za 1914 god, 1915: 26-27.

${ }^{7}$ Statements for 1876 (Otchet ... za 1876 god, 1884: 72).

8 Statements for 1886 (Otchet ... za 1888 god, 1885: 76).

9 Ibid.

${ }^{10}$ Statements for 1912 (Dokhody, raskhody, spetsialnye kapitaly i zadolzhennost gorodskikh poseleniy na 1912 god, 1917: 148).

${ }^{11}$ Statements for 1912 (Dokhody, raskhody, spetsialnye ..., 1917: 149). 
said that cities often could not do without the help of the government or the provincial administration in the implementation of large projects to improve the urban economy (Sakharov, Bokhanov, Gatagova, 2002: 130).

Fourthly, within our consideration, despite the small size, the budget revenues of the provincial and county cities of the Ekaterinoslav Province, together with the expenditures of the city treasuries, show a steady tendency to increase rapidly. These processes outpaced the rate of inflow of the population from outside to the relevant cities.

Thus, the decisions of state control institutions generally did not hinder the budget policy of municipal selfgovernment institutions to create a financial basis for their powers and did not hinder the implementation of important plans. However, all municipal budget activities were under the strict control of state supervisory institutions, which in the performance of their functions mostly had no claims to the City Dumas about exercising their budgetary powers, corrected erroneous decisions of regulatory institutions of city public administration. However, sometimes misunderstanding of the legal requirements of imperial law took place when performing supervisory functions.

Sometimes the city self-governments in the exercise of their powers faced with the zemstvos against the background of state control over the legality and correctness of their decisions. For example, in the autumn of 1906, the Mariupol City Duma stated the inconvenience of the calendar time of the beginning of three city fairs, namely Yevdokiyevsky, Uspensky and Pokrovsky, established in accordance with the Duma resolutions in 1882 and 1883. The untimely opening of the bidding resulted in their disadvantage for both the local population and visiting buyers, as well as for fair traders, due to a number of circumstances. In particular, the yarding by peasants and the sale of cattle began long before the official start of the fair. These cattle were bought by young women at relatively low prices. With the official opening of the bidding, the buyers resold what they bought to those who came to the fair to buy cattle for their own needs with great benefit for themselves. On the other hand, the peasants who sold their cattle to the cattle dealer so as not to waste time did not wait for the opening of a fair where they could buy something for themselves and let the fair dealer bargain. As a result, many people eventually suffered as a result of this situation. To eliminate these circumstances, on November 15, 1896, the Mariupol City Duma passed a resolution to open the Assumption and Intercession Fairs five days before the holiday the names of which the bidding had ${ }^{12}$.

This decision was revoked on February 1, 1897 by the Provincial Presence on the grounds that the Regulations on Provincial and County Zemstvo Institutions gave the right to change the dates of existing fairs only by the Provincial Zemstvo Assembly. Given these circumstances, on February 27, 1897, the Mariupol Duma appointed the city council to initiate a petition through the Mariupol County Zemstvo to the Ekaterinoslav Provincial Zemstvo Assembly to change the dates of the start of fairs in Mariupol. The reaction of the executive body of the public administration was, for unknown reasons, somewhat slow. Only on July 4, 1897, in a written appeal to the Ma-

\footnotetext{
12 The State Archive of Donetsk region, Fund 113, List 1, File 205, P. 1, 2.
}

riupol Zemstvo, the city council asked to report its request to change the established dates of the fairs to the Provincial Zemstvo Assembly.

Time passed, and the Mariupol city council did not receive any response to its petition from the provincial zemstvo. Due to the fact that the results of the appeal to the provincial local self-government body had not been known for a long time, on May 12, 1900, i.e. in two years and ten months, the city council appealed to the Mariupol County Zemstvo Council for the consequences of its petition $^{13}$. In response, the Head of the County Zemstvo Administration Gozadinov said that the regular session of the Provincial Zemstvo Assembly agreed to postpone the fairs, but the relevant resolution had been submitted for approval by the Minister of Internal Affairs so far ${ }^{14}$. We do not know the further course of the case from the available documents.

As we can see, more than three and a half years had passed from the first attempt of the Mariupol City Duma to postpone the terms of the trade fair appointed at November 15, 1896 (adoption of an illegal resolution) to the information about the Ekaterinoslav Provincial Assembly's approval of this change in May 1900. An obvious reason for such slowness was a mixture of excessive state centralization with bureaucratic delays and dishonest delays in office administration in many parts of both zemstvo and city self-government.

Tough relations developed between the Luhansk City Duma and the county zemstvo, the institutions of which were located in Luhansk as the administrative center of the Slovianoserbsk County. In particular, in the first years of the 20th century, the County Council, under the authority of the Zemstvo Assembly, filed a complaint with the Senate against the governor of Ekaterinoslav, who refused to grant the county zemstvo's request to encourage the Luhansk city public administration to establish a city hospital. On the other hand, the Luhansk Mayor, on behalf of the Duma, appealed to the Senate against the refusal to satisfy the official request of the city administration to expand the zemstvo hospital based in Luhansk.

Based on the provision of the municipal law that the establishment of charitable institutions and hospitals by law was only a right but not an obligation of city public administrations, on February 27, 1902, the Senate decided not to satisfy the complaints of the zemstvo council. At the same time, with its second decision, it decided to leave the appeal of the Luhansk Mayor without consequences. The Senate decision was based on the fact that zemstvos were not obliged to expand the zemstvo hospitals established and subordinated to them upon the request of city institutions. However, this dry legal formula was enriched by an emotional non-legal detail - "if they do not have the funds for such an expansion" (Mantsevich, 1911: 75-76).

The implementation of state supervision over municipal self-government in the Ekaterinoslav Province was often faced with opposing views, aspirations, interests of public administration bodies in secondary issues of municipal organization or rules of purchase and sale of goods. In particular, the Luhansk City Duma, even before the introduction of the City Regulation in 1892, decided to set up bollards that restricted the passage of the lane

\footnotetext{
${ }^{13}$ Ibid, P. 3-6.

14 Ibid, P. 7.
} 
between Angliskaya Street and the pond. The Provincial Presence revoked this decision on the grounds of a restriction on the passage of vehicles. The Senate, for its part, on September 22, 1892, found the decision of the supervisory institution correct, and dismissed the complaint of the city council (Kantorovich, 1903: 180).

Sometimes the Provincial Presence was unreasonably captious. In particular, the decision of the Luhansk City Duma to lease city seats on Novobazarnaya Square, reserved for meat trade without public bidding, was revoked. By a decision of June 20, 1896, the Senate upheld the complaint of Luhansk Mayor Verbovsky, declaring the Presence's decision unjustified because the City Regulations did not provide for mandatory bidding in this regard (Kantorovich, 1903: 562).

The decision of the Presence in the second half of the 1890 s to repeal the resolution of the Mariupol City Duma, which forbade parking empty carts on the market square and on the adjacent streets, looks trivial. This order, appealed in the Senate, was overturned as illegal on October 13, 1898. The justification of the relevant Senate resolution was based on paragraphs 11,12 of art. 108 of the City Regulation, which gave the Duma the right to make mandatory regulations on markets and bazaars and on security measures and traffic on the streets (Kantorovich, 1903: 871).

Taking into account previous experience of more than 25 years, the Oleksandrivsk City Duma in order to protect the local population from the desire of fish traders to increase prices sharply, on December 9, 1897, decided to establish a tax on fresh fish. Quite quickly, on January 24, 1898, the Provincial Presence repealed this resolution (Otchet o deyatelnosti Aleksandrovskogo gorodskogo obshchestvennogo upravleniya za 1898 god, 1899: 2021). It took less than a month for the Oleksandrivsk City Duma to formulate an order to the Mayor to appeal the decision of the Presence (February 17, 1898). However, the complaint did not find support in the Senate. The Senate decision of October 5, 1899 was as follows: Oleksandrivsk City Duma went beyond its powers, because art. 127 of the Charter on national food by the city administration gave the right to lay taxes which were approved by the governor only on "the most necessary" - baked bread and meat. The long journeys of the appeal against the decision of the Presence attract attention here - 19 full months passed from the formulation of the protest to its rejection.

In this case, what is remarkable is that the provincial supervisory authority noticed a violation of the law only when it was headed by Head of the Province Pyotr Dmitrievich Svyatopolk-Mirsky (governor since December 30, 1897). Until then, for a quarter of a century, the governors either had not paid attention or intentionally had not noticed the illegality of the decision of the Oleksandrivsk City Duma on the tax on fresh fish. Thus, the personality of the Head of the province as the chief official in the organization of supervision of the city public administration was important.

In the early 20th century, the Head of the province sent an order to the police department in Luhansk, in which he tried to clarify the opening of shopping venues on Sundays and holidays, namely - their opening was possible only after the liturgy in the cathedral church. This administrative instruction was appealed by the Mayor in the Senate. In the motivational part of his protest, the Head of the city administration explained that parishion- ers were able to open shops after the liturgy in their parish church, regardless of whether the service in the neighboring churches had ended or not. This rule was established by a mandatory regulation adopted by the City Duma and approved by the former governor and followed from art. 14 of the Statute on the Prevention and Suppression of Crimes. At the same time, the Mayor stressed that the instruction of the current Head of the province restricted the rights of traders (Mantsevich, 1911: 161-162).

In turn, in a report to the Senate, the governor explained his position by the desire to establish order and equality in trade. Another argument by the Head of the province that it was necessary to enable the police to monitor the merchants' compliance with the mandatory order seems to be at least a violation of formal logic. Another motivation was of an unserious nature: the order was needed to eliminate the "monopoly of commercial establishments" in those parishes where the liturgy ended earlier than in others (Mantsevich, 1911: 162). In fact, in our opinion, the governor's order looks like a covert act of retribution for something to Luhansk municipalities.

Everything in the decision of the Senate of June 18, 1903 concerning this case was put in its place within the framework of imperial law. Due to the fact that the governor's order to open commercial establishments only after the liturgy in the cathedral church was not in line with the mandatory regulation in force in Luhansk, the Senate order repealed the first one (Mantsevich, 1911: 163).

Among the documents we found there is only one which contains information about the application of the Ekaterinoslav governor of the norm of art. 83 of the City Regulation which allowed to stop execution of the order of the City Duma on the basis of violation of interests of "local population". The report of the Oleksandrivsk City Public Administration for 1901 contains information about the condemnation of a plot of city land in favor of the Second Catherine Railway and at its request. In August 1901, the Oleksandrivsk City Duma decided to move building for the tank of the city water supply from one place to another. The execution of this resolution was suspended for unknown reasons by a decision of the Governor, which was supported by the Presence. However, the Ministry of Internal Affairs did not see any violations of "local interests" in considering the case. Therefore, the city selfgovernment of Oleksandrivsk received satisfaction in a separate local confrontation with the supervisory state authority. However, this did not require an appeal against its decision - the legislative mechanism provided for in art. 86 City Regulations worked (Polnoe sobranie zakonov Rossijskoj imperii, 1895: 446).

A sharp, unpredictable clash of opinions took place at a meeting of the Mariupol City Duma on July 1, 1908 during a discussion of the issue of state taxation, city and zemstvo fees for real estate in the city of Mariupol. The main focus of the councilors was on the report of the evaluation and layout commission. The key point in this was to determine the value of real estate and the layout of taxes on property owners. At the same time, the petitions of eleven homeowners to reduce the set value (respectively taxes from them) of their buildings due to its inconsistency with the level of profitability announced by the chairman of the meeting Ivan Popov were considered. Only one request was granted.

The Jewish councilor Isai Matetsky made an official statement "on duty of conscience and the oath taken" that 
complaints about incorrect valuations of real estate were filed only by "Jews or Russians" (by the way, all the names of the complainants, whom Matetsky called Russians, had signs of Ukrainian origin). This circumstance, according to the councilor, indicated the bias of the evaluation and layout commission and condescension to the Greek real estate owners. Due to this statement, the meeting of the City Duma was outraged. Many spoke of the oppositionist's misconception. Councilor D. Kharadzhaev began to prove the falsity of Matetsky's statement, to confirm it, he read a list of 129 people whose property value was increased by the commission for the current year. Among them was a very large number of Greeks.

After listening to the explanations of Kharadzhaev and others, the councilor Matetsky announced that he was taking back his words. But the excited meeting adopted a decision: to express the condemnation to the councilor $I$. Ye. Matetsky for the public accusation against the evaluation and layout commission which did not fully deserve it (Zhurnaly ocherednykh i chrezvychaynykh zasedaniy Mariupolskoy gorodskoy dumy za 1908 g., 1907: 146149). Matetsky appealed against this decision in the Provincial Presence, which in turn, referring to the decision of the Senate on a similar case in previous times, determined to cancel the decision of the Duma on the condemnation. The main motivation for this decision was the reasoning formulated by the Senate: The Duma could approve or condemn the councilor only for fulfilling the duties assigned to the councilor by the Duma (Zhurnaly ... Mariupolskoy gorodskoy dumy za 1908 g., 1907: 375). This decision of the Provincial Presence was heard at a meeting of the Mariupol City Duma on December 4, 1908. The Duma decided to "take note and guide" (Zhurnaly ... Mariupolskoy gorodskoy dumy za 1908 g., 1907: 353). Awareness of being wrong stopped the general combative mood of the councilors in defending their positions, the conflict was over.

\section{Conclusions}

The cities of Ekaterinoslav Province became a field of embodiment of a powerful social transformation of the last third of the 19th - early 20th centuries. At this time, migration was gaining momentum, providing a significant increase in the population of the provincial and the vast majority of county cities. At the same time, the industrial revolution came to the cities of the province. The growth of entrepreneurial activity had provided an increase in cash income to city budgets, among others, in the form of city taxes. This increased expenses on the solution of issues of urban management, which were closely monitored by government regulators.

The social orientation of the activity of city selfgovernments of Ekaterinoslav Province has been established. Their expenditures provided a priority increase in spending on schooling and medicine, veterinary and sanitary units. State control institutions generally did not interfere with the budget policy of municipal self-government institutions and its humanitarian component, although misunderstandings sometimes arose.

The implementation of state control over public administrations in the Ekaterinoslav Province often faced the aspirations of self-government bodies in secondary issues of municipal organization which were incompatible with the law in the opinion of its hosts. Disputes arose mostly on the basis of different understandings of the rules of sale and purchase of goods, measures to regu- late traffic on city streets etc. Among other things, the importance of the governor's personality in the administrative supervision, as well as the facts of triviality of guardianship, are striking. The role of the Presence in the matter of settling disputes within the Mariupol City Duma on the basis of the requirement of formal observance of the law seems irreplaceable.

When exercising their powers in the field of control over the compliance with the law by city self-governments, state institutions at the provincial level sometimes showed inappropriate competence in the field of interpretation of imperial legislation, which resulted in erroneous decisions. Certain decisions of public administrations of cities sometimes also violated the requirements of the law and were subject to unconditional suspension or revocation.

The City Dumas of the province widely used the legally regulated opportunity to defend their decisions in the Senate. The specific Senate cases started in connection with the supervision over the legality of decisions of city self-governments and the provincial presence for the zemstvo and city affairs give the impression that they were considered on the basis of a qualified verification of compliance with imperial law.

It was not easy to resort to bureaucratic arbitrariness in the relationship of the Head of the province with public administration. The single fact that the governor used the right to suspend the execution of the resolutions of the city council on the basis of violation of the interests of the "local population" when controlling the city self-government indicates the difficulty of implementing this rule of municipal law. The involvement of the highest government bodies of the empire hindered this procedure.

Against the background of state supervision, disputes arose between city self-governments and the zemstvo. And the clash with state institutions did not preclude interference in the dispute of the Head of the relevant ministry, who could push the decision necessary for his department outside the Senate, contrary to current law.

We found that the administrative control was implemented slowly, and formulations of thoughts on appealing the decisions of the Provincial Presence were deprived of speed and efficiency. The provincial zemstvo sinned against evading operative decisions. At the same time, there is a dishonest delay in the circulation of documents in all parts of public administration and local self-government.

In general, no complete coherence in the relationship between state supervisory institutions and city selfgovernments of the Ekaterinoslav Province can be seen. However, in our opinion, a principled relationship was established, limited by the framework of business ethics in the field of public administration, taking into account the imperial guidelines for superiors and subordinates.

Acknowledgement. We express our sincere gratitude to all members of the editorial board for the consultations provided during the preparation of the article for publication.

\section{REFERENCES}

Blinov, I. A. \& Gagen, V. A. \& Gogel, S. K. (1911). Istoriya Pravitelstvuyushchego senata za dvesti let. 1711-1911 gg. (T. 4). St.Petersburg: Senatskaya tipografiya (in Russian).

Brower, D. (1990). The Russian City Between Tradition and Modernity, 1850-1900. Berkeley: University of California Press.

Dokhody, raskhody, spetsialnye kapitaly i zadolzhennost gorodskikh poseleniy na 1912 god. (1917). Petrograd: Tip. N. Ya.Stoykovoy (in Russian). 
Kantorovich, Ya. A. (Comps.). (1903). Sbornik opredeleniy Pervogo departamenta Pravitelstvuyushchego senata po gorodskim i zemskim delam za 10 let (1891-1900). SanktPeterburg (in Russian).

Korobka, V. M. (2010). Hromadske upravlinnia u mistakh Katerynoslavskoi hubernii $(1870-1914$ rr.) (Extended abstract of Candidate's thesis). Donetsk [in Ukrainian].

Kratkiy obzor deyatelnosti Yekaterinoslavskoy gorodskoy upravy za 1913 god. (1914). Yekaterinoslav: Tip. byvsh. Bratstva Sv. Vladimira (in Russian)

Mantsevich, P. D. (Comps.). (1911). Ukazy Senata po gorodskim delam (1900-1910). Yaroslavl (in Russian).

Obzor Yekaterinoslavskoy gubernii za 1887 god. (1888). Yekaterinoslav: Tipo-Lito Gub. prav. (in Russian).

Obzor Yekaterinoslavskoy gubernii za 1914 god. (1915). Yekaterinoslav: Tipo-Lito Gub. prav. (in Russian).

Otchet Bakhmutskoy gorodskoy upravy za 1913 god. (1914). Bakhmut: Tip. I.I. Derkovskogo (in Russian).

Otchet o denezhnykh oborotakh gorodskikh kass za 1872 god. (1885). Sankt-Peterburg: Tip. Min. vnut. del (in Russian).

Otchet o denezhnykh oborotakh gorodskikh kass za 1873 god. (1889). Sankt-Peterburg: Tip. Min. vnut. del (in Russian).

Otchet o denezhnykh oborotakh gorodskikh kass za 1874 god (1889). Sankt-Peterburg: Tip. Min. vnut. del (in Russian).

Otchet o denezhnykh oborotakh gorodskikh kass za 1876 god. (1884). Sankt-Peterburg: Tip. Min. vnut. del (in Russian).
Otchet o denezhnykh oborotakh gorodskikh kass za 1884 god. (1885). Sankt-Peterburg: Tip. Min. vnut. del (in Russian).

Otchet o deyatelnosti Aleksandrovskogo gorodskogo obshchestvennogo upravleniya za 1898 god. (1899). Aleksandrovsk: Tip. B. Ya. Shterna (in Russian).

Pamyatnaya knizhka Yekaterinoslavskoy gubernii na 1875 god. (1875). Yekaterinoslav: Tip. gub. Pravleniya (in Russian).

Polnoe sobranie zakonov Rossijskoj imperii. (1895). Vol. 12: 430-456. Sankt-Peterburg (in Russian).

Reient, O. P. (1993). Robitnytstvo Ukrainy i Tsentralna Rada. Istorychni zoshyty, (10), 1-47. Retrieved from: http://resource.history.org.ua/publ/Preprint_1993_10_1_(in Ukrainian).

Sakharov, A. N., Bokhanov, A. N., Gatagova, L. S. (2002). Rossiya v nachale XX veka. Moskva: Novyy khronograf (in Russian).

Shandra, V.S. (2012). Cenat Rosiiskoi imperii, Pravytelstvuiuchyi Senat. V. A. Smolii (Red.), Entsyklopediia istorii Ukrainy (T. 9., ss. 529-530). Kyiv: Naukova dumka (in Ukrainian).

Vsya Yekaterinoslavskaya guberniya na 1913 god. (1913). Yekaterinoslav: Tip. gub. Pravleniya (in Russian).

Zhurnaly ocherednykh i chrezvychaynykh zasedaniy Mariupolskoy gorodskoy dumy za 1908 g. (1907). Mariupol: Tip. Br. E. i A. Goldrin (in Russian).

Вадим Коробка,

Маріупольський державний університет (м. Маріуполь, Украӥна)

e-mail:v.korobka@mdu.in.ua,ORCID0000-0002-2030-498X

Юлія Коробка,

Маріупольський державний університет (м. Маріуполь, Україна)

e-mail: j.korobka@mdu.in.ua,ORCID0000-0003-4518-4264

\section{АДМІНІСТРАТИВНИЙ НАГЛЯД ЗА ДІЯЛЬНІСТЮ МІСЬКИХ САМОВРЯДУВАНЬ КАТЕРИНОСЛАВСЬКОЇ ГУБЕРНІї (1870 - 1913) (частИна 2)}

У статті розкрито значення адміністративного нагляду за міськими самоврядуваннями у Катеринославській губернії (1870 - 1913). Встановлено їх соціальну спрямованість. У видатках забезпечувалося пріоритетне зростання витрат на шкільництво та медицину, ветеринарну і санітарну частини. Державні контрольні інституції, в основному, не перешкоджали кошторисній політиці установ міського самоврядування та її гуманітарній складовій, хоча часом виникали непорозуміння. Розкрито, що реалізація в Катеринославській губернії державного контролю за громадськими управліннями нерідко стикалась із несумісними з законом, на погляд його носіїв, прагненнями органів самоврядування в другорядних питаннях організації міського господарства. Суперечки виникали здебільшого на ґрунті неоднакового розуміння правил купівлі-продажу товарів, заходів упорядкування руху вулицями міст тощо. Підтверджено, що при здійсненні повноважень у сфері контролю за додержанням міськими самоврядуваннями законності державні інституції губернського рівня виявляли часом неналежну компетентність у галузі тлумачення імперського законодавства, що мало наслідком прийняття помилкових ухвал. Окремі рішення громадських управлінь міст часом теж порушували імперське законодавство та підлягали безумовній зупинці або скасуванню. Доведено, що громадські управління губернії широко користувались законодавчо унормованою можливістю захисту своїх рішень у Сенаті. Вивчені конкретні сенатські справи, заведені у зв'язку із наглядом за законністю ухвал міських самоврядувань та губернського в земських та міських справах Присутствія, складають враження, розглянутих на ґрунті кваліфікованої перевірки відповідності імперському законодавству. Встановлено, що адміністративний контроль супроводжувався неспішним провадженням, а формулювання в Думі оскарження рішень губернського Присутствія були позбавлені швидкості та оперативності. Ухилянням від прийняття рішень грішило губернське земство. Водночас спостерігається несумлінне затримування документообігу в усіх ланках державного управління й місцевого самоврядування.

Ключові слова: Катеринославська губернія; міське громадське управління; самоврядування; губернатор; Катеринославське губернське в земських і міських справах Присутствіє; Сенат; міська дума; міський бюджет.

(C) Vadym Korobka, Yuliia Korobka

Надійшла до редакції: 17.05.2021

Прийнята до друку: 16.07.2021 